\title{
Cause Determination of the Adjustable-Rate Mortgage Market Collapse During the Financial Crisis
}

\author{
Ryan P. Wang ${ }^{1}$ \\ ${ }^{1}$ Greenhills School, Ann Arbor, Michigan, United States \\ Correspondence: Ryan Wang, Greenhills School, 850 Greenhills Dr., United States. E-mail: \\ ryan.wang.mi@gmail.com
}

Received: August 8, 2020

Accepted: October 3, 2020

Online Published: October 20, 2020

doi:10.5539/ijef.v12n11p83

URL: https://doi.org/10.5539/ijef.v12n11p83

\begin{abstract}
This paper provides insight into what caused the decline of the adjustable-rate mortgage (ARM) market during the 2007-2009 financial crisis. Contrary to common perception, the failure of the ARM market cannot be primarily attributed to predatory lending targeting subprime borrowers from low-credit households. This popular narrative is incomplete and disregards some important factors. I present three key factors that challenge the narrative and point to previously undiscussed sources that may have contributed to the ARM market collapse. First, the accusation of predatory lending does not account for other possible causes of mass ARM defaults. Second, the sole focus on the market's subprime segment disregards the impact of prime ARMs on the market. Third, the narrative's citation of subprime ARMs having greater delinquency rates and foreclosure numbers fails to recognize the significant percentage increase in prime ARM failures in the years leading up to the crisis, as well the disparity in typical outstanding balances between subprime and prime ARMs.
\end{abstract}

Keywords: adjustable-rate mortgage, complex mortgage, default, delinquency, financial crisis, market collapse, mortgage market

\section{Introduction}

Financial crises are nothing new. Chaos erupted in the Roman Empire after an anti-usury law was revived in 33 CE. This law required creditors to invest a percentage of their capital in Italian land to be able to lend at interest, causing creditors to call in all their loans to meet the new land requirements. Debtors, unable to meet the creditors' sudden demands, attempted to sell land to raise funds for repayment. This credit crisis resulted in a collapse in land values and a shortage of credit throughout the Roman Empire (Bartlett, 2018).

Crises in the financial sector that influence the overall economy like the one that befell Rome in $33 \mathrm{CE}$ are recurring phenomena throughout history. Despite the long history of financial crises, there is still widespread debate among economists on the causes and potential cures of these events. The elusive nature of financial crises is best illustrated by the 2007-2009 financial crisis, widely regarded as the most devastating financial crisis in recent history since the Great Depression. This particular crisis nearly instigated the complete collapse of the global financial system, sparking the resulting economic fallout of the Great Recession. With the entire world's economy in jeopardy, governments bailed out many of the major financial institutions deemed "too big to fail" to prevent a further economic catastrophe. However, a significant amount of damage had already been done.

The 2007-2009 financial crisis left a drastic impact on the U.S. economy, Property values plummeted for the first time in decades with the Case-Shiller index recording a 27.4\% drop in house prices between 2006 and 2012. Amid the slowdown in business activity, the unemployment rate peaked at $10 \%$ in October of 2009 , amounting to a loss of nearly 8.7 million jobs. Estimates put the loss of total U.S. wealth to be as high as $\$ 15$ to $\$ 40$ trillion, about 100\%-190\% of the country's output in 2007 (Thakor, 2015).

These severe effects of the 2007-2009 financial crisis serve as a stark reminder of the importance of studying financial crises. The careful examination of this crisis paves the way towards a better understanding of the underlying causes of the crisis and how to prevent it from happening again. This is, unfortunately, easier said than done. There is still no clear consensus among academics on the causes of the crisis, and the debate on the effectiveness of regulation implemented after the fallout rages on (Coffee Jr., 2009). 


\section{Background}

Amid the discussions on the financial crisis of 2007-2009, a narrative of what caused the crisis has gained traction in popular culture and the academic community. The widely accepted narrative focuses on the subprime borrowing of mortgages leading up to the financial crisis and points to predatory lending targeted at low-credit households as a significant cause of the mortgage market meltdown (Ross \& Squires, 2011). Inside Job, a highly acclaimed 2010 documentary, promoted this narrative with its director describing the film as highlighting "the systemic corruption of the United States by the financial services industry and the consequences of that systemic corruption" (Ferguson, 2012). Following the wake of the recession, a significant component of the narrative became the surge in popularity of mortgages with complicated loan terms in the years leading up to the financial crisis. The complexity of these mortgages was supposedly able to mislead financially unsophisticated, low-credit borrowers into taking on loans that they were unable to repay. The adjustable-rate mortgage was one such "complex" mortgage.

Similar to other "complex mortgage types," the adjustable-rate mortgage, or ARM for short, underwent a rapid rise and subsequent decline in popularity throughout the duration of the financial crisis. In contrast with traditional mortgages with fixed interest rates, the ARM has a varied interest rate throughout the duration of the loan. Interest rates on ARMs are recalculated periodically as the summation of a varying index rate - usually tied to the interest rate of the one-year Treasury bill — and a constant margin rate. The hybrid ARM is a particular variant of the ARM that is frequently referenced in discussions on the 2007-2009 financial crisis. As its name suggests, this hybrid variant has an initial period of fixed interest rates followed by the period of adjusting interest rates based on the ARM's index. These ARMs yielded a significantly greater number of defaults compared to their fixed-rate counterparts (Bergstresser \& Beshears, 2010). By 2007, ARMs experienced a rapid decline in popularity, reaching a cumulative distribution of nearly 0 in terms of its share in the overall mortgage market (Amromin et al., 2018). Figure 1 visualizes this pattern in ARM borrowing.

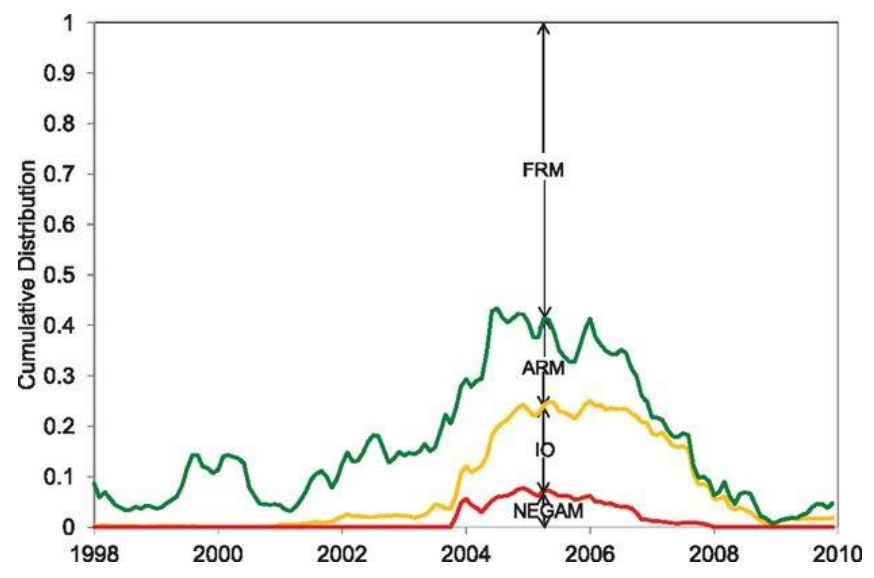

Figure 1. Growth and collapse of the ARM market

Source: LPS Applied Analytics (Amronmin et al., 2018).

The collapse of the ARM segment of the mortgage market seems to fit the popular narrative's notion that mortgages with complicated loan terms misguided financially unsophisticated borrowers from low-credit households. ARM borrowers supposedly took on "toxic" mortgages without being properly informed of their loan terms by mortgage originators, who engaged in predatory lending in pursuit of greater profits. This idea of mortgage toxicity portrays ARMs as "wired to explode," luring in financially unsophisticated borrowers with low teaser rates then slamming them with higher interest rates during the adjustable phase. While the narrative appears straightforward, its veracity requires an evidence-based analysis of its explanation. To shed light on the underlying causes of the collapse of the ARM market during the 2007-2009 financial crisis, this paper deconstructs the popular narrative's argument on ARMs and examines its validity.

\section{Argument}

Contrary to the popular narrative, the view that the collapse of the ARM market during the financial crisis was primarily caused by predatory lending towards low-credit households is incomplete and does not consider some important factors. This paper examines three distinct components of the narrative and challenges the points made 
by each. These components are the labeling of subprime ARM origination as predatory lending, the sole focus on the subprime segment of the ARM market, and the disparity in delinquencies and foreclosures between the subprime and prime ARM markets.

\subsection{Accusation of Predatory Lending}

The first reason why the popular narrative is incomplete is due to its accusation of predatory lending without taking into account other possible causes of ARM defaults. The narrative pushes the idea that low-credit households were targeted by the originators through methods that can be labeled as predatory lending. Colloquially, predatory lending can be loosely described as any lending practice that exploits borrowers with unfair and abusive loan terms. However, it has no precise definition with uniform agreement. Rather, the practice is understood among consumer advocates, mortgage lenders, and regulators as an "I know it when I see it" occurrence (Azmy, 2005). Without a clearly defined framework, discerning what is and isn't predatory is challenging. Nevertheless, the popular narrative makes the assumption that the widespread practice of predatory lending caused the vast majority of financially unsophisticated borrowers from low-credit households to default on their ARMs. "Predatory" loan terms allegedly deceived these borrowers into taking out ARMs that were financially unsustainable.

However, this assumption does not take into account any other possible cause as to why low-credit borrowers defaulted on their ARMs. The issue of high default rates on ARMs may actually reside in the combination of mortgage underwriting standards and the decline in house prices in the years leading up to the financial crisis. Slacked underwriting standards allowed originators to issue complex mortgage products like ARMs with low to no down payments. The complexity of ARMs itself was not the issue though, as borrowers who took issue with their loan terms had the option to refinance into a different mortgage. This only changed after underwriting standards were tightened as the markets adjusted for the relaxed underwriting.

The problem, rather, was that low to no down payment ARMs resulted in households having dangerously high loan-to-value (LTV) ratios, essentially making their houses highly leveraged (Mayer et al., 2009). A higher LTV ratio means that a greater percentage of the house's appraised value is in debt. These ARMs with low to no down payments were innocuous during the period of real estate growth from the 1980s through the mid-2000s. In fact, they were key to making mortgages more accessible to more Americans. The incentives provided by these mortgages with low to no down payments made buying a home cheaper than renting, granting families with stable but modest incomes the ability to become homeowners (Fritz, 2019). These ARMs with low to no down payments only became prone to defaults after house prices started declining in 2006 and refinancing into a different mortgage became difficult due to tightened underwriting standards. This is because a decline in house values corresponds with a drop in home equity, the difference between a home's appraised value and the outstanding balance of the mortgage on that home. Borrowers that took out low to no down payment mortgages start with smaller equity, making their equity more likely to be completely wiped out and go negative amid the widespread decline in house prices. Known as becoming "underwater" on mortgages, this status of negative home equity incentivizes homeowners to default on their loans as the optimal economic decision (Gerardi et al., 2008). Although the combination of low to no down payment ARMs and declining house prices resulted in the high default rates in the ARMs market, it is difficult to make the leap of labeling low to no down payment ARM origination as predatory lending. The lack of explicitly unfair or abusive loan terms in ARMs and the unclear framework of what constitutes predatory lending counters the popular narrative's idea that low-credit borrowers were preyed on by ARM originators.

Other possible causes aside, the narrative's reliance on the belief that ARMs caused confusion and uninformed financial decision making among low-credit, financially unsophisticated borrowers is still problematic. Robert Gnaizda, director at the Greenlining Institute, recalled Alan Greenspan saying, "If you had a doctorate in math, you wouldn't be able to understand [adjustable-rate mortgages] enough to know which was good for you and which wasn't" (Ferguson, 2012). Despite this rhetoric, there does not seem to be any concrete evidence linking "borrower confusion" with defaults on ARMs. If such confusion surrounding ARM loan terms did indeed exist, then there should be an exorbitant number of defaults on ARMs as they reset from their fixed-rate period to the adjustable-rate period. However, as Figure 2 indicates, no such pattern exists. 


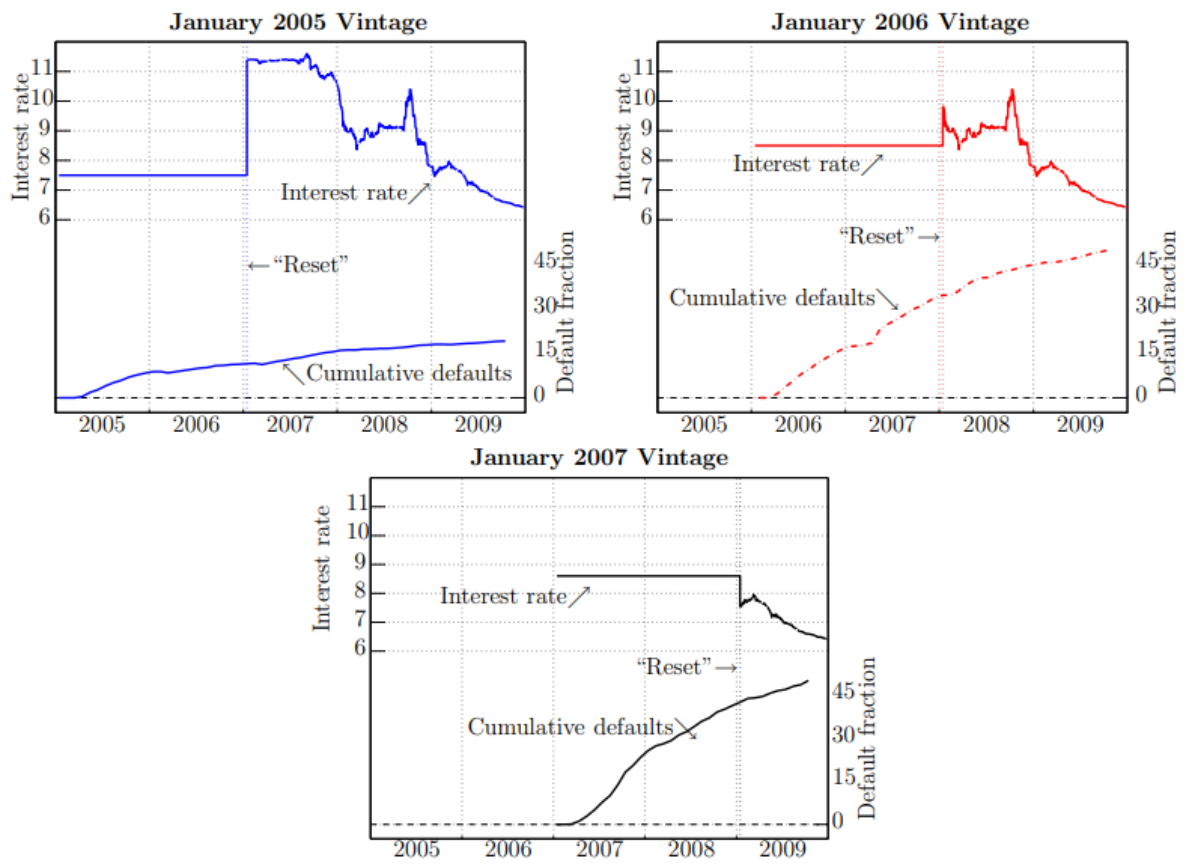

Figure 2. Cumulative defaults for three subprime ARMs

Source: Lender Processing Services, Inc. (Foote et al., 2012).

Defaults on subprime ARMs in the years leading up to the financial crisis generally did not spike when their interest rates reset and entered the adjustable phase, meaning that the increased payments following the transition did not lead to defaults (Foote et al., 2012). This evidence opposes the narrative's idea that ARMs were designed to fail by its "predatory" originators.

\subsection{Role of Subprime and Prime ARMs}

The second reason as to why the popular narrative is incomplete is because its explanation of what caused the collapse of the ARM market focuses solely on the market's subprime segment. The explanation problematically dismisses the prime segment of the ARM market altogether and does not take into account any possible influence it had on the market collapse. This is because the narrative hinges on the argument that the ARM market leading up to the financial crisis was being predominantly driven by unsophisticated borrowers who were more financially vulnerable. Therefore, it would appear that issuing ARMs for these more financially unsophisticated borrowers, whether the lending was predatory or not, was significantly more impactful on the market than it otherwise would have been. This view appears to be supported by an analysis of the general profile of ARM borrowers. From 1989 to 2001, a trend towards increased use of ARMs among lower-income, less wealthy, less creditworthy, and single-headed households appeared (Finke et al., 2006). If this trend was to be extrapolated into the 2000s up to the financial crisis, it would make sense to assume that the ARM market was dominated more heavily by subprime mortgages compared to the FRM market, hence the disparity between the two markets' default rates. This evidence points to the popular narrative's argument that low-credit households and their "toxic" ARMs were the primary cause of the ARM market collapse.

However, the truth is more complicated. In the years leading up to the financial crisis, the ARM market was driven not only by the low-credit households. Rather, the market was also greatly influenced by financially sophisticated households that took advantage of higher interest rate spreads between ARMs and FRMs (Smith et al., 2011). This patently refutes the validity of the narrative's subprime-centric focus on the ARM market. In fact, the overall mortgage market experienced increased originations for borrowers across all income levels and credit scores (Adelino et al., 2016). The evidence from these sources indicates that the trend of increased ARM originators among low-credit households in the years leading up to the financial crisis was not unique. If the growth in popularity in subprime ARMs borrowed by less financially sophisticated households was matched by a corresponding growth for prime ARMs borrowed by more financially sophisticated households, then subprime ARMs did not undergo a significant increase in its share of the ARM market. By only focusing on the subprime segment of the ARM market and citing its growth, though, the popular narrative fallaciously concludes there was subprime dominance in the ARM market. Therefore, the assumption that the ARM market 
was being predominantly driven by subprime ARMs from low-credit households cannot be made without further evidence.

Furthermore, prime ARMs borrowed by middle- and high-income borrowers with greater financial sophistication were more influential to the market compared to their subprime counterparts. This is because higher-income borrowers had greater outstanding balances on their ARMs relative to lower-income borrowers, so prime ARMs had greater starting principal values. Data from the Home Mortgage Disclosure Act (HMDA) shows that the average purchase mortgage in the lowest income quartile of ZIP codes was about $\$ 97 \mathrm{k}$ as of 2002 , whereas borrowers in the top quartile of ZIP codes obtain average mortgages of over \$246k (Adelino et al., 2016). A disparity between the values of prime and subprime ARMs this large highlights the larger impact that prime ARMs have on the ARM market through their greater monetary value. Again, this indicates that the belief that subprime ARMs drove the market is largely incorrect, further showing the imprecise nature of the popular narrative.

\subsection{Disparity in Delinquencies and Foreclosures}

The third reason regarding the incomplete nature of the popular narrative is the faulty citation of a disparity in delinquencies and foreclosures between the subprime and prime segments of the ARM market. In accordance with the popular narrative's focus on subprime ARMs, proponents of the narrative point out the higher rate of delinquencies and foreclosure numbers for subprime ARMs compared to prime ARMs as evidence that the failure of subprime ARMs led to the collapse of the overall ARM market. Although the disparity does exist, this does not necessarily mean that subprime ARMs borrowed by financially unsophisticated borrowers were the primary cause of the market collapse.

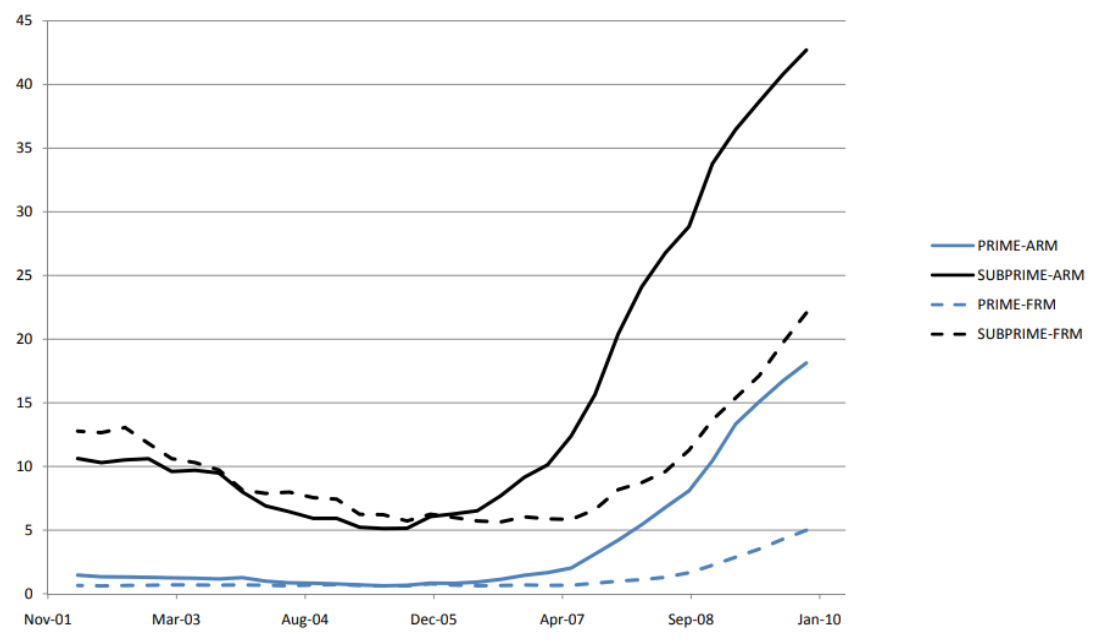

Figure 3. Percent of seriously delinquent mortgages, 2001-2010

Source: Mortgage Bankers Association (Bergstresser \& Beshears, 2010).

A Chicago Fed Letter from 2007 accentuates the focus on subprime delinquencies: "We show that the subprime mortgage market is facing substantial problems, as measured by delinquency rates, while the prime mortgage market is experiencing more typical delinquency rates..." (Agarwal \& Ho, 2007). A greater share of subprime ARMs indeed became seriously delinquent relative to prime ARMs. As shown in Figure 3, more than $40 \%$ of subprime ARMs were delinquent by the end of 2009, whereas only $18 \%$ of prime ARMs were delinquent (Bergstresser \& Beshears, 2010). This data appears to validate the popular narrative's focus on subprime ARMs as the prime instigators of the ARM market collapse during the crisis, but it hinges on a direct, causal relationship connecting delinquency rates and foreclosure numbers to the market collapse.

This direct relationship, however, is not entirely accurate. Firstly, subprime loans are inherently more likely to become delinquent and lead to defaults. Low-credit borrowers who take out subprime loans are typically members of middle- to lower-income households that have a less stable income. This uncertainty makes these borrowers less credible in terms of paying off their loans, so these subprime loans are naturally riskier than prime loans. Therefore, subprime ARMs having higher delinquency rates and foreclosure numbers compared to prime ARMs in the years leading up to the financial crisis is not a new phenomenon.

Secondly, delinquency rates on both prime and subprime ARMs increased dramatically starting in mid-2006. In 
fact, prime ARM delinquencies incurred a much greater percent growth as the financial crisis erupted. Between December of 2005 and January of 2010, the percentage of prime ARMs that became seriously delinquent increased by nearly nineteen times over, while the percentage of subprime ARMs increased by slightly less than seven times over. This means that although subprime ARMs sustained higher overall delinquency rates, prime ARM delinquencies surged more than subprime ARMs during the crisis relative to their respective pre-crisis rates. A similar result can be found upon examining the foreclosures among subprime and prime ARMs throughout the 2000s. While the share of ARM foreclosures encompassed nearly $6 \%$ of the subprime segment and $1.2 \%$ of the prime segment by the final quarter of 2007, the prime segment of the ARM market sustained a greater influx of foreclosures relative to its foreclosure numbers before the crisis. Between the fourth quarters of 2004 and 2007, subprime ARM foreclosures increased threefold, whereas prime ARM foreclosures increased slightly more than sixfold.

The substantial difference in delinquencies and foreclosures suggests that prime ARMs were actually more affected during the financial crisis than subprime ARMs. Although the subprime segment of the ARM market had higher delinquency rates and a greater number of foreclosures, this has always been a recurring phenomenon due to the riskier nature of low-credit borrowers who take subprime loans. Instead, the percentage changes of delinquency rates and foreclosure numbers before and during the crisis indicate that prime ARMs degraded into a more dangerous investment vehicle compared to before the crisis. This finding stands in direct contradiction with the popular narrative's point on the "toxicity" of subprime ARMs being the leading cause of the ARM market collapse.

Besides the disparities in percent changes, the direct relationship attributing the collapse of the ARM market to subprime ARMs for its higher delinquency rates and foreclosure numbers does not take into account the difference in impact each subprime and prime ARM makes on the market. This same mistake appears in the popular narrative's determination that subprime ARMs predominantly drove the market in the years leading up to the financial crisis. Because prime ARMs typically have greater outstanding balances compared to subprime ARMs, a single prime ARM exerts a greater influence on the overall market compared to a single subprime ARM. By the same logic, delinquencies and defaults on prime ARMs are more detrimental to the market than their subprime counterparts. This concept is illustrated by the model represented in Figure 4 .

Table 1. Unweighted ARM market

\begin{tabular}{lcccccc}
\hline ARM Type & Quantity & Value & Delinquency Rate (Pre-crisis) & Delinquency Rate (Post-crisis) & Market Share & Market Impact \\
\hline Subprime ARMs & 50 & $\$ 150,000$ & $6.5 \%$ & $42.5 \%$ & $50 \%$ & $\$ 2,700,000$ \\
Prime ARMs & 50 & $\$ 150,000$ & $1.0 \%$ & $18.5 \%$ & $50 \%$ & $\$ 1,312,500$ \\
\hline
\end{tabular}

Table 2. Weighted ARM market

\begin{tabular}{ccccccc}
\hline ARM Type & Quantity & Value & Delinquency Rate (Pre-crisis) & Delinquency Rate (Post-crisis) & Market Share & Market Impact \\
\hline Subprime ARMs & 50 & $\$ 100,000$ & $6.5 \%$ & $42.5 \%$ & $26.7 \%$ & $\$ 1,800,000$ \\
Prime ARMs & 50 & $\$ 275,000$ & $1.0 \%$ & $18.5 \%$ & $73.3 \%$ & $\$ 2,406,250$ \\
\hline
\end{tabular}

Source: Author estimates based on HMDA data. The value of prime ARMs can be set as low as $\$ 205,715$ and still illustrate the concept that prime ARMs likely had a larger impact on the market compared to subprime ARMs due to their typically greater outstanding balances.

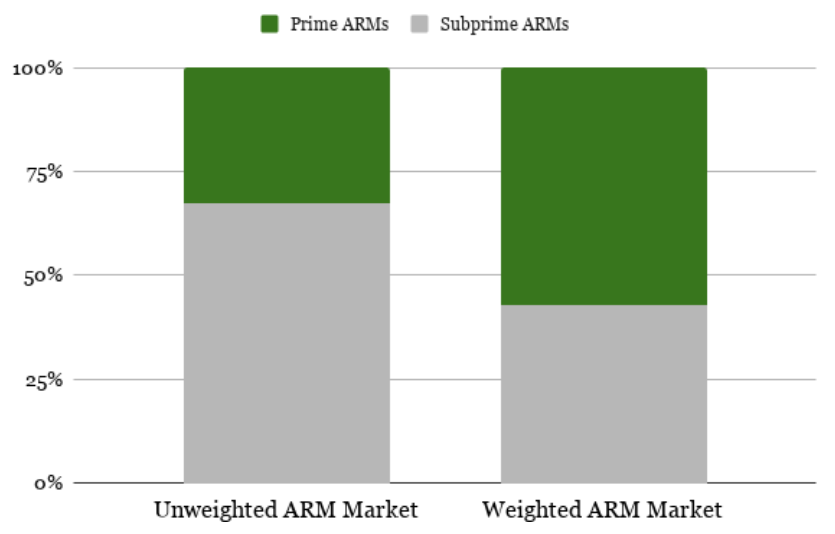

Figure 4. Prime ARM Delinquency Impact 
The model is divided into two versions of the ARM market: unweighted and weighted. The unweighted version of the market simulates the popular narrative's view of the ARM market during the financial crisis. By setting subprime and prime ARMs at the same value, the unweighted version disregards the disparity in outstanding balances between the two ARM types. In the absence of this disparity, subprime and prime ARMs have equal footing in the market. This causes subprime ARM delinquencies to have a greater impact on the market since subprime ARMs had significantly more delinquencies compared to prime ARMs. The unweighted version of the ARM market seems to affirm the direct, causal relationship linking subprime ARMs' higher delinquency rates and foreclosure numbers to the market collapse.

However, the unweighted version's fundamental flaw of disregarding the value disparity between subprime and prime ARMs invalidates its simulation of the ARM market. In contrast, the weighted version of the market takes into account the difference in the two ARM types in terms of dissimilar outstanding balances. This version indicates the greater market share prime ARMs have, as well as the greater impact their delinquencies have on the ARM market. By comparing the unweighted and weighted versions of the ARM market, the model shows that prime ARMs had a larger role to play in causing the ARM market collapse than the popular narrative seems to suggest.

Both the significant percentage increase in delinquencies and foreclosures on prime ARMs in the years leading up to the financial crisis and the disparity in typical outstanding balances between the subprime and prime ARMs are indication that subprime ARMs' high delinquency rates and foreclosure numbers were not the sole cause of the ARM market collapse.

\section{References}

Adelino, M., Schoar, A., \& Severino, F. (2016). Loan originations and defaults in the mortgage crisis: The role of the middle class. The Review of Financial Studies, 29(7), 1635-1670. https://doi.org/10.1093/rcfs/cfv001

Agarwal, S., \& Ho, C. T. (2007). Comparing the prime and subprime mortgage markets. Federal Reserve Bank of Chicago, Essay on Issues, (241).

Amromin, G., Huang, J., Sialm, C., \& Zhong, E. (2018). Complex mortgages. Review of Finance, 22(6), 1975-2007. https://doi.org/10.1093/rof/rfy016

Azmy, B. (2005). Squaring the Predatory Lending Circle. Fla. L. Rev., 57, 295. https://doi.org/10.2139/ssrn.594042

Bartlett, C. (n. d.). The Financial Crisis, Then and Now: Ancient Rome and 2008 CE. Retrieved from https://epicenter.wcfia.harvard.edu/blog/financial-crisis-then-and-now

Bergstresser, D., \& Beshears, J. (1989). Who selected adjustable-rate mortgages? Evidence from the 1989-2007 Surveys of Consumer Finances. SSRN Electronic Journal. https://doi.org/10.2139/ssrn.1573625

Coffee Jr, J. C. (2009). What went wrong? An initial inquiry into the causes of the 2008 financial crisis. Journal of Corporate Law Studies, 9(1), 1-22. https://doi.org/10.1080/14735970.2009.11421533

Ferguson, C. (2012). Inside job: The financiers who pulled off the heist of the century. Simon and Schuster.

Finke, M. S., Huston, S. J., Siman, E., \& Corlija, M. (2006). Characteristics of recent adjustable-rate mortgage borrowers. Journal of Financial Counseling and Planning, 16(2).

Foote, C. L., Gerardi, K. S., \& Willen, P. S. (2012). Why did so many people make so many ex post bad decisions? The causes of the foreclosure crisis (No. w18082). National Bureau of Economic Research. https://doi.org/10.2139/ssrn.2479576

Fritz, M. J. (2019, August 09). Federal Housing Administration (FHA). Retrieved from https://www.britannica.com/topic/Federal-Housing-Administration

Gerardi, K., Lehnert, A., Sherlund, S. M., \& Willen, P. (2008). Making sense of the subprime crisis. Brookings Papers on Economic Activity, 69-145. https://doi.org/10.2139/ssrn.1341853

Mayer, C., Pence, K., \& Sherlund, S. M. (2009). The rise in mortgage defaults. Journal of Economic perspectives, 23(1), 27-50. https://doi.org/10.1257/jep.23.1.27

Ross, L. M., \& Squires, G. D. (2011). The personal costs of subprime lending and the foreclosure crisis: a matter of trust, insecurity, and institutional deception. Social Science Quarterly, 92(1), 140-163. https://doi.org/10.1111/j.1540-6237.2011.00761.x

Smith, H. L., Finke, M. S., \& Huston, S. J. (2011). The impact of financial sophistication on adjustable rate 
mortgage ownership. Journal of Financial Counseling and Planning, 22(2).

Thakor, A. V. (2015). The financial crisis of 2007-2009: Why did it happen and what did we learn?. The Review of Corporate Finance Studies, 4(2), 155-205. https://doi.org/10.1093/rcfs/cfv001

\section{Appendix A}

\section{Creating the ARM Market Model}

\section{Market Impact Calculation}

The impact that subprime and prime ARM delinquencies inflicted on the market was calculated using the following equation:

$$
\text { Market Impact }=(\text { Quantity Value })(\text { Post-crisis Delinquency Rate }- \text { Pre-crisis Delinquency Rate })
$$

I used the difference in the delinquency rates rather than just the post-crisis rate to place greater emphasis on delinquency rate change during the crisis. This emphasis assists in determining the true cause of the ARM market collapse by negating the state of the market before the financial crisis.

\section{Quantity Simplification}

To focus on the disparity of outstanding balances between subprime and prime ARMs, I limited the complexity of the model by setting up both versions of the market to have an equal number of the two ARM types. While this simplification may not accurately reflect the distribution of subprime and prime ARMs in the real-world market during the financial crisis, the general concept of the model still stands: the popular narrative's overrepresentation of subprime failures and underrepresentation of prime failures in terms of market impact.

\section{Copyrights}

Copyright for this article is retained by the author(s), with first publication rights granted to the journal.

This is an open-access article distributed under the terms and conditions of the Creative Commons Attribution license (http://creativecommons.org/licenses/by/4.0/). 